\title{
Mortality of Sardinian lead and zinc miners: 1960-88
}

\author{
P L Cocco, P Carta, S Belli, G F Picchiri, M V Flore
}

\section{Abstract}

The mortality of 4740 male workers of two lead and zinc mines was followed up from 1960 to 1988 . Exposure to respirable dust was comparable in the two mines, but the median concentration of silica in respirable dust was 10 -fold higher in mine $B(12 \cdot 8 \%)$ than in mine $A(1 \cdot 2 \%)$, but the mean annual exposure to radon daughters in underground workplaces differed in the opposite direction (mine A: 0.13 working levels (WL), mine B: 0.011 WL). Total observed deaths (1205) were similar to expected figures (1156.3) over a total of 119390.5 person-years at risk. Underground workers of mine $B$ had significant increases in risk of pulmonary tuberculosis (SMR 706, 95\% confidence interval (95\% CI) 473-1014) and non-malignant respiratory diseases (SMR 518; 95\% CI 440-1606), whereas the only significant excess at mine $A$ was for non-malignant respiratory diseases (SMR 246; 95\% CI 191-312). Total cancer and lung cancer mortality did not exceed the expectation in the two mines combined. A $15 \%$ excess mortality for lung cancer, increased up to an SMR 204 (95\% CI 89-470) for subjects employed $\geqslant 26$ years, was, however, found among underground workers in mine $A$ who on the average experienced an exposure to radon daughters 10 -fold higher than those of mine $B$. By contrast, despite their higher exposure to silica, mine $B$ underground workers experienced a lower than expected lung cancer mortality. A ninefold increase in risk of peritoneal and retroperitoneal cancer combined was also found among underground workers of mine A (SMR 917; 95\% CI 250-2347; based on four deaths). A causal association with workplace exposures is unlikely, however, as the SMR showed an inverse trend by duration of employment. These findings are consistent with low level exposure to radon daughters as a risk factor for lung cancer among metal miners. Exposure to silica at the levels estimated for the mine $B$ underground environment did not increase the risk of lung cancer.

(Occup Environ Med 1994;51:674-682)

Keywords: metal miners, radon daughters, silica, lung cancer
Based on epidemiological findings and laboratory experiments on animals, the International Agency for Research on Cancer (IARC) considers silica as a probable lung carcinogen in humans. ${ }^{12}$ Recently, however, Holland has questioned the use of these laboratory findings for setting new standards in workplaces. ${ }^{3}$ Epidemiological evidence of an increased risk of lung cancer seems stronger among patients with silicosis, ${ }^{4-10}$ although negative findings have been reported in patients with silicosis from gold mines in South Africa ${ }^{112}$ and lead and zinc mines in Sardinia. ${ }^{13}$ Studies of populations with relatively pure exposure to crystalline silica have yielded conflicting results; positive findings have been reported, ${ }^{14-17}$ but inconsistency of trends, ${ }^{7}$ contrasting results by type of mine where exposure to silica occurred, ${ }^{18}$ or by workplace within the same industry, ${ }^{19}$ and difficulties in distinguishing between effects of silica and other concomitant carcinogenic exposures $^{20}$ have suggested the need for further studies to explore the association in detail.

Radon daughters may be an important risk factor for lung cancer among metal miners, ${ }^{21}$ who are also typically exposed to respirable dusts containing crystalline silica. The availability of measurements of silica and products of radon decay in underground mines has led to an interpretation of excess risks of lung cancer being probably related to exposure to radon daughters. ${ }^{22}{ }^{23} \mathrm{~A}$ recent study conducted by Carta et al in two Sardinian metal mines, where it was possible to distinguish exposure to silica from exposure to radon daughters, provided evidence that risk of lung cancer increased only among metal miners exposed to low levels of radon daughters in one of the two mines, and that subjects with airways obstruction were more prone to develop lung cancer. ${ }^{24}$

We have further investigated the risk of developing lung cancer by studying the mortality experience among Sardinian metal miners considering separately the effects of exposure to low levels of radon daughters and silica.

Material and methods

STUDY POPULATION

Lists of all workers of two metal mines located in Sardinia, a region of Italy, were retrieved from company registers. Eligible cohort members were men, with at least one year of 
employment between 1932 and 1971, and still employed on 1 January 1960 , or who had worked a minimum of 12 months consecutively between 1 January 1960 and 19 September 1971, when the mines changed ownership. Two men with unknown duration of employment were excluded from the study. Each man contributed to follow up from 1 January 1960 or after having completed 12 months from the date of hiring. The cohort included 4740 men, $2096(44 \cdot 2 \%)$ from mine A, $2603(54.9 \%)$ from mine B, and $41(0.9 \%)$ who worked in both mines. The cohort was followed up for mortality until 30 November 1988. In total, 119390.5 person-years were accumulated. Vital status was known for $99.5 \%$ of cohort members (4714/4740) and the total number of deaths was 1205 . Death certificates were available for 1198/1205 $(99.4 \%)$ of the deceased men. The underlying causes of death were coded by an expert nosologist according to the International Classification of Diseases-9th revision (ICD9). The present study population includes 1741 men, 906 from mine $A$ and 835 from mine $B$, who in 1973 participated in a cross sectional survey of the active workforce of the two mines, and who had been separately considered in a previous study. ${ }^{24}$ Important differences from the previous study are a completely different study design with a longer follow up, and a much larger population size and number of deaths (1205 in the present study $v 187$ in the other publication).

\section{ASSESSMENT OF EXPOSURE}

Details of industrial hygiene data are reported in a previous paper. ${ }^{24}$ Briefly, the ores extracted in both mines are mainly blende and galena (lead and zinc sulphides), and the matrix consists of dolomite and limestone (mainly carbonates) in mine $\mathrm{A}$, and metamorphic schist (mainly quartz and syderite) in mine B. Mining procedures were identical in the two mines over the period of the study. Regular measurements of airborne dust from personal and static sampling devices were available starting in the $1960 \mathrm{~s} .{ }^{25-27}$ Respirable dust concentrations were comparable in the two mines, with mean concentrations in underground workplaces declining from $2.5-2.6 \mathrm{mg} / \mathrm{m}^{3}$ in $1962-70$, to $1.6-1.8 \mathrm{mg} / \mathrm{m}^{3}$ from 1971 onwards. Concentrations around 3-5 $\mathrm{mg} / \mathrm{m}^{3}$ were retrospectively estimated to have occurred in both mines in 1945-60, based on a few available measurements, production per year, and changes in ventilation and drilling devices. Dust concentrations at surface workplaces averaged $<1 \mathrm{mg} / \mathrm{m}^{3}$ in both mines from the 1970 s. The median quartz content in respirable dust remained constant in both mines over the period for which measurements were available, with a $1: 10$ ratio between the two mines (mine A: $1 \cdot 2 \%$; mine B: $12 \cdot 8 \%$ ), so that it is assumed not to have varied, even before the follow up period. ${ }^{24}$

Measurements of underground $\alpha$ radiation produced by radon daughters were made available by the National Agency for Nuclear and Alternative Energy (ENEA) and the
Institute of Radiological Protection of the National Hydrocarbons Corporation (ENI), who provided confidential reports to the mining companies. They covered the period from 1972 in mine $A$ and were more numerous in 1988-89, when some measurements were also performed in mine B. Mean exposure to $\alpha$ energy was 0.13 working levels (WL) among underground workers in mine $A$ and 0.011 WL among underground workers in mine $B .^{24}$ No data were available on polycyclic aromatic hydrocarbons released by diesel engines in the mining environment. Diesel powered transport equipment came into use in the early 1970 s, when $48 \%$ of cohort members (2272/4741) were still employed. The main gases from diesel exhausts (carbon monoxide, nitrogen, and sulphur oxides) in the underground air environment were below the threshold limit value time weighted average (TLV-TWA) limits in both mines with rare exceptions, ${ }^{26}$ suggesting that exposure to polycyclic aromatic hydrocarbons may also have been low.

\section{STATISTICAL METHODS}

Expected deaths were derived from the regional rates specific for five year age groups and calendar year of follow up between 1960 and 1988 as reviewed by a group of Italian epidemiologists, who met in 1992-3 to deal with the problem of the proper calculation of expected number of events with the latest version of the ICD coding system throughout the period of follow up (unpublished report). Nationwide and regional mortality rates for 1960-90 were made available for major groups of causes and selected causes of death which, by taking into account the variations in the coding system throughout this period, allowed attribution of the most recent code to the same disease in the overall period of follow up. Standardised mortality ratios (SMRs), together with their $95 \%$ confidence intervals (95\% CIs), were calculated for the total cohort and various subcohorts with OCMAP PC. ${ }^{28}$ The Poisson trend statistic was used to evaluate the significance of the trends.

\section{Results}

Mean (SD) age at the start of mining was $27 \cdot 7$ $(10.6)$ years among cohort members in mine $A$ and $30.0(7.8)$ years in mine B. More than $65 \%(3099 / 4741)$ of cohort members were hired before 1960 , and only $1 \%(50 / 4741)$ after 1965. Duration of employment $>10$ years for $68.2 \%$ of cohort members, and was longer in mine A $(17 \cdot 0(7 \cdot 8)$ years) than mine B (11.2 (7.3) years). Dates of changes in job titles were available for all cohort members, but information on periods at specific underground workplaces within the same mine was not. The average exposure to radon progeny for all underground workplaces of each mine was considered too rough a measurement to yield reliable individual estimates. It was therefore decided to rely on duration of employment in underground jobs as a surrogate for exposure. 
Table 1 Sardinia (Italy), two lead and zinc mines (1960-88): standardised mortality ratios and 95\% confidence intervals by cause of death: total cohort

\begin{tabular}{|c|c|c|c|c|}
\hline$I C D-9$ codes & Cause of death & Obs & $\operatorname{Exp}$ & $\operatorname{SMR}(95 \% C I)$ \\
\hline $001-999 \cdot 9$ & All causes & 1205 & $1156 \cdot 3$ & $104(98-110)$ \\
\hline $001-139 \cdot 8$ & Infectious and parasitic diseases & 44 & $19 \cdot 1$ & $203(167-309)$ \\
\hline $011-011 \cdot 9$ & Pulmonary tuberculosis & 38 & $11 \cdot 5$ & $329(233-452)$ \\
\hline $140-239 \cdot 9$ & All cancers & 293 & $312 \cdot 6$ & $94(83-105)$ \\
\hline $140-149 \cdot 9$ & Oral cavity and pharynx & 8 & $13 \cdot 0$ & $61(26-121)$ \\
\hline $150-159 \cdot 9$ & Digestive system & 86 & $103 \cdot 5$ & $83(66-103)$ \\
\hline $150-150 \cdot 9$ & Oesophagus & 6 & $6 \cdot 8$ & $89(32-193)$ \\
\hline $151-151 \cdot 9$ & Stomach & 27 & $28 \cdot 7$ & $94(62-137)$ \\
\hline $152-154 \cdot 8$ & Intestine and rectum & 12 & $18 \cdot 7$ & $64(33-112)$ \\
\hline $155-155 \cdot 2$ & Liver & 16 & $25 \cdot 8$ & $62(35-126)$ \\
\hline $157-157 \cdot 9$ & Pancreas & 10 & $14 \cdot 7$ & $68(33-125)$ \\
\hline $158-158 \cdot 9$ & Peritoneum and retroperitoneum & 6 & $1 \cdot 6$ & $367(135-798)$ \\
\hline $160-165 \cdot 9$ & Respiratory system & 98 & $105 \cdot 7$ & $93(75-113)$ \\
\hline $161-161 \cdot 9$ & Larynx & 11 & $13 \cdot 7$ & $80(40-144)$ \\
\hline $162-162.9$ & Trachea, bronchi, lung & 86 & $90 \cdot 8$ & $95(76-117)$ \\
\hline $163-163.9$ & Pleura & 1 & $1 \cdot 3$ & $79(2-438)$ \\
\hline 185 & Prostate & 16 & $13 \cdot 2$ & $121(69-197)$ \\
\hline $188-188 \cdot 9$ & Bladder & 17 & $14 \cdot 8$ & $115(67-184)$ \\
\hline $189-189 \cdot 9$ & Kidney & 7 & $5 \cdot 5$ & $128(52-264)$ \\
\hline $191-192.9$ & Nervous system & 8 & $6 \cdot 9$ & $117(50-230)$ \\
\hline $200-208 \cdot 9$ & Lymphohaemopoietic system & 21 & $23 \cdot 0$ & $91(56-139)$ \\
\hline 200,202 & Non-Hodgkin's lymphomas & 6 & $5 \cdot 2$ & $116(42-252)$ \\
\hline $250-250 \cdot 9$ & Diabetes & 9 & 23.8 & $38(17-72)$ \\
\hline $390-459.9$ & Cardiovascular diseases & 258 & $406 \cdot 5$ & $63(56-72)$ \\
\hline $460-519.9$ & Respiratory diseases & 300 & $97 \cdot 5$ & $308(274-345)$ \\
\hline $520-579 \cdot 9$ & Digestive diseases & 85 & 117.9 & $72(58-89)$ \\
\hline $571-571 \cdot 9$ & Liver cirrhosis & 46 & $81 \cdot 1$ & $57(41-76)$ \\
\hline $580-599 \cdot 9$ & Urinary diseases & 29 & $18 \cdot 2$ & $160(107-229)$ \\
\hline $800-999.9$ & External causes & 104 & $111 \cdot 6$ & $93(76-113)$ \\
\hline
\end{tabular}

TOTAL COHORT

Table 1 shows the results for the total cohort. Mortality from all causes was close to expectation. Significant increases were found for non-malignant respiratory diseases, infectious diseases (due to a significant increase in pulmonary tuberculosis), and genitourinary diseases. Significant deficits in mortality were found for cardiovascular diseases, digestive diseases, and particularly cirrhosis of the liver and diabetes, which may be due to a very careful medical selection of the workforce before employment. Among genitourinary diseases, glomerulonephritis (10/29 cases), and kidney failure (seven acute cases, four chronic cases, three unspecified cases) were most frequently reported. Rheumatoid arthritis was reported as an underlying cause of death in two underground workers in mine $B$ with five and eight years of employment respectively. Rheumatoid arthritis was also reported as a concurrent disease in the death certificate of another underground worker in mine $B$ who died of respiratory failure subsequent to silicosis. No other immunological diseases of the connective tissue, including lupus and scleroderma, were found after an extensive search of all causes of death reported on the death certificates.

Mortality for all cancers combined was also lower than expected. Among single cancer sites, peritoneal and retroperitoneal cancerjointly considered in the available reference rates - showed a significant, almost fourfold increase, with six observed deaths $v \quad 1.6$ expected. Kidney, bladder, and prostate cancer showed non-significant excesses ranging from $15 \%$ to $28 \%$. A slight excess was also found for cancer of the central nervous system (eight observed $v 6.9$ expected), whereas lymphohaemopoietic tumours were below the expectation. Six out of the 21 observed lymphatic tumours were non-Hodgkin's lymphomas (ICD-9 codes 200 and 202), a number close to the $5 \cdot 2$ expected.

\section{UNDERGROUND $v$ SURFACE WORKERS}

Table 2 shows the mortality experience of underground and surface workers of the two mines combined. Mortality for all causes was significantly higher than expected among underground workers, whereas it was slightly lower among surface workers. The excess was due to an almost fourfold increase in mortality from non-malignant respiratory diseases (NMRD) and a 4.6-fold increase from pulmonary tuberculosis. The SMR for genitourinary diseases had increased equally in both surface and underground workers. Deaths from glomerulonephritis occurred mainly among surface workers (6/10 cases), whereas $12 / 14$ deaths from kidney failure occurred among underground workers. Mortality from cardiovascular diseases was significantly lower among both surface and underground workers. It must be added that deaths from diabetes were only $28 \%$ of the expected figure among underground workers, and $68 \%$ among surface workers.

Mortality from all cancers was equally below expectation among surface and underground workers. The only significant increase in SMR was found for peritoneal and retroperitoneal tumours among underground workers. The SMR was similar among surface workers but was not significant. Mortality from lung cancer did not differ between surface and underground workers of the two mines combined. Cancers of the genitourinary tract and the central nervous system were in excess among underground workers, and non-Hodgkin's lymphomas were in excess among surface workers (four observed $v 1 \cdot 7$ expected), but none of the risks was significant.

UNDERGROUND WORKERS: MINE A $v$ MINE B Mortality from all causes was significantly higher among underground workers in mine $B$, whereas only a non-significant $2 \%$ excess was observed in mine A. Most causes of death 
Table 2 Comparison between surface and underground workers of both mines (administrative personnel excluded): each subcohort includes cohort members who ever held a job in surface of underground workplaces; therefore, subjects who worked both in surface and underground workplaces appear twice

\begin{tabular}{|c|c|c|c|c|c|}
\hline \multirow[b]{2}{*}{ ICD-9 code } & \multirow[b]{2}{*}{ Cause of death } & \multicolumn{2}{|c|}{ Surface } & \multicolumn{2}{|c|}{ Underground } \\
\hline & & Obs & SMR (95\% CI) & Obs & $\operatorname{SMR}(95 \% C I)$ \\
\hline $\begin{array}{l}001-999 \cdot 9 \\
001-139 \cdot 8 \\
011-011 \cdot 9 \\
140-239 \cdot 9 \\
140-149 \cdot 9 \\
150-159 \cdot 9 \\
150-150 \cdot 9 \\
151-151 \cdot 9 \\
152-154 \cdot 8 \\
155-155 \cdot 2 \\
157-157 \cdot 9 \\
158-158 \cdot 9 \\
160-165 \cdot 9 \\
161-161 \cdot 9 \\
162-162 \cdot 9 \\
163-163 \cdot 9 \\
185 \\
188-188 \cdot 9 \\
189-189 \cdot 9 \\
191-192 \cdot 9 \\
200-208 \cdot 9 \\
200,202 \\
250-250 \cdot 9 \\
390-459 \cdot 9 \\
460-519 \cdot 9 \\
520-579 \cdot 9 \\
571-571 \cdot 9 \\
580-599 \cdot 9 \\
800-999 \cdot 9\end{array}$ & $\begin{array}{l}\text { All causes } \\
\text { Infectious and parasitic diseases } \\
\text { Pulmonary tuberculosis } \\
\text { All cancers } \\
\text { Oral cavity and pharynx } \\
\text { Digestive system } \\
\text { Oesophagus } \\
\text { Stomach } \\
\text { Intestine and rectum } \\
\text { Liver } \\
\text { Pancreas } \\
\text { Peritoneum and retroperitoneum } \\
\text { Respiratory system } \\
\text { Larynx } \\
\text { Trachea, bronchi, lung } \\
\text { Pleura } \\
\text { Prostate } \\
\text { Kidney } \\
\text { Bladder } \\
\text { Central nervous system } \\
\text { Lymphohaemopoietic system } \\
\text { Non-Hodgkin's lymphomas } \\
\text { Diabetes } \\
\text { Cardiovascular diseases } \\
\text { Respiratory diseases } \\
\text { Digestive diseases } \\
\text { Liver cirrhosis } \\
\text { Urinary diseases } \\
\text { External causes }\end{array}$ & $\begin{array}{r}384 \\
9 \\
4 \\
101 \\
3 \\
32 \\
3 \\
10 \\
7 \\
6 \\
3 \\
2 \\
36 \\
3 \\
33 \\
5 \\
2 \\
4 \\
2 \\
10 \\
4 \\
6 \\
88 \\
75 \\
25 \\
11 \\
12 \\
38\end{array}$ & $\begin{array}{r}92(83-102) \\
136(62-258) \\
98(27-252) \\
91(75-110) \\
66(14-193) \\
85(58-120) \\
126(26-368) \\
94(45-173) \\
104(42-215) \\
64(24-140) \\
57(12-166) \\
351(42-1269) \\
97(68-134) \\
63(13-83) \\
104(71-145) \\
\overline{(1-)}(-2) \\
94(31-220) \\
105(13-379) \\
72(20-185) \\
91(11-327) \\
128(61-235) \\
230(63-590) \\
68(25-148) \\
57(46-71) \\
202(159-253) \\
61(39-90) \\
40(20-71) \\
179(92-312) \\
109(77-149)\end{array}$ & $\begin{array}{r}796 \\
33 \\
33 \\
185 \\
5 \\
51 \\
2 \\
16 \\
6 \\
9 \\
7 \\
4 \\
63 \\
8 \\
54 \\
1 \\
10 \\
4 \\
13 \\
6 \\
9 \\
1 \\
4 \\
160 \\
224 \\
56 \\
33 \\
16 \\
67\end{array}$ & $\begin{array}{c}113(105-121) \\
275(189-386) \\
460(317-646) \\
96(83-111) \\
61(20-143) \\
81(60-106) \\
47(6-171) \\
93(53-151) \\
53(19-114) \\
57(26-108) \\
78(31-160) \\
390(106-999) \\
96(73-122) \\
94(40-184) \\
95(72-125) \\
126(3-703) \\
134(64-247) \\
117(32-299) \\
148(79-253) \\
133(49-290) \\
62(28-117) \\
30(1-168) \\
28(8-72) \\
66(56-77) \\
390(341-445) \\
76(57-99) \\
64(44-90) \\
146(84-238) \\
90(70-115)\end{array}$ \\
\hline
\end{tabular}

showed similar SMRs in the two mines, with a few striking exceptions. Underground workers in mine $B$ had a fivefold excess mortality from non-malignant respiratory diseases, compared to a $2 \cdot 5$-fold excess in mine $A$. This cause, together with the sevenfold excess for pulmonary tuberculosis, accounts for the excess for all causes seen in mine B (table 3). Underground workers in mine A had only a non-significant $28 \%$ increase in mortality from pulmonary tuberculosis. Deaths from cardiovascular diseases were below expectation in both mines, but particularly in mine $B$, where also, no deaths from diabetes were observed $v$ the 7.8 expected. Therefore, it is reasonable to assume that the medical selection in this mine was particularly effective. Deaths from kidney failure were almost evenly distributed between the two mines.

Mortality from lung cancer was $15 \%$ higher than expected in mine A, although the SMR was not significant, and lower than expected in mine B. A case of pleural cancer was also observed in mine $A v$ the 0.3 expected, but no cases of pleural cancer were reported in mine B. The SMR for lung cancer tended to increase by duration of employment among underground workers in mine $A$, with the highest value among subjects employed for $\geqslant 26$ years (SMR 204; 95\% CI 89-470),

Table 3 Comparison between underground workers in the two mines: each subcohort includes all cohort members who ever held underground jobs in that mine; therefore subjects who worked in both mines appear twice




Table 4 Non-malignant respiratory diseases (NMRD), pulmonary tuberculosis, and lung cancer by years of employment in underground jobs and mine

\begin{tabular}{|c|c|c|c|c|c|c|}
\hline \multirow[b]{2}{*}{ Mine } & \multicolumn{5}{|c|}{ Duration of employment (y) } & \multirow{2}{*}{$\begin{array}{l}\text { Test for } \\
\text { trend }\end{array}$} \\
\hline & $\leqslant 10$ & $11-15$ & $16-20$ & $21-25$ & $>26$ & \\
\hline \multicolumn{7}{|l|}{ Pulmonary tuberculosis: } \\
\hline A & $140(1 / 0 \cdot 7)$ & $268(2 / 0 \cdot 75)$ & - & $161(1 / 0 \cdot 6)$ & - & 0.42 \\
\hline$\stackrel{\text { B }}{\text { NMRD. }}$ & NMRD: & $1059(10 / 0.9)$ & $832(7 / 0 \cdot 8)$ & - & - & $0 \cdot 22$ \\
\hline A & $203(11 / 5.4)$ & $287(18 / 6 \cdot 3)$ & $265(19 / 7 \cdot 2)$ & $256(15 / 5 \cdot 9)$ & $172(5 / 2 \cdot 9)$ & 0.01 \\
\hline B & $386(44 / 11 \cdot 4)$ & $613(48 / 7 \cdot 8)$ & $637(47 / 7 \cdot 4)$ & $539(14 / 2 \cdot 6)$ & $338(3 / 0.9)$ & $2 \cdot 03$ \\
\hline$\geqslant 26$ y after start of employment & $316(15 / 4 \cdot 7)$ & $644(39 / 6 \cdot 1)$ & $695(46 / 6 \cdot 6)$ & $538(14 / 2 \cdot 6)$ & $337(3 / 0 \cdot 9)$ & $4 \cdot 40^{\star}$ \\
\hline \multicolumn{7}{|c|}{ Lung cancer: } \\
\hline $\begin{array}{l}\text { A } \\
B\end{array}$ & $\begin{array}{l}68(4 / 5 \cdot 9) \\
78(14 / 18 \cdot 0)\end{array}$ & $\begin{array}{r}118(7 / 5 \cdot 9) \\
73(6 / 8 \cdot 2)\end{array}$ & $\begin{array}{c}143(10 / 7 \cdot 0) \\
63(5 / 8 \cdot 0)\end{array}$ & $\begin{array}{l}100(7 / 7 \cdot 0) \\
122(4 / 3 \cdot 3)\end{array}$ & $\begin{array}{l}204(5 / 2 \cdot 4) \\
135(1 / 0 \cdot 7)\end{array}$ & $\begin{array}{l}1.47 \\
0.26\end{array}$ \\
\hline
\end{tabular}

${ }^{\star} \mathrm{p}<0.05$ Poisson trend statistic

(table 4). The highest SMR for lung cancer among underground workers in mine $B$ was also found among subjects employed $\geqslant 26$ years, but it was generated by one observed death $v 0.7$ expected. The analysis by latency showed no trend in either mine, but $26 / 33$ lung cancer cases in mine $A$ and $17 / 30$ in mine $B$ occurred $\geqslant 26$ years after the start of exposure.

All four cases of peritoneal and retroperitoneal cancer found among underground workers occurred in the mine A subcohort (SMR 917), but the SMR showed an inverse trend by duration of employment (data not shown). Only one of the four cases occurring in this subcohort was reported as "peritoneal carcinosis" in the death certificate, $v$ three cases of retroperitoneal cancer. Deaths from cancers of the genitourinary and central nervous systems were evenly distributed between underground workers of the two mines.

SURFACE WORKERS: MINE A $v$ MINE B

Surface workers showed a similar pattern of mortality in the two mines, again with a few exceptions (table 5). An almost fourfold excess mortality from non-malignant respiratory disease was shown also among surface workers from mine $B$, whereas only a nonsignificant $13 \%$ excess was seen in mine $A$. Cancer of the oesophagus, cancer of the kidney, and non-Hodgkin's lymphomas were in excess among surface workers in mine A, but only two deaths were found from each. Surface workers in mine B showed a $24 \%$ excess of lung cancer, a $2 \cdot 3$-fold excess of prostate cancer, and a 3.3-fold excess of nonHodgkin's lymphomas, although none was significant. Pulmonary tuberculosis, nonmalignant respiratory diseases, and lung cancer did not increase by length of employment among surface workers of the two mines (table 6).

\section{Discussion}

The present study of the cohort allowed an investigation of the mortality of Sardinian metal miners, with a partial separation of the effects of exposure to silica and low levels of radon progeny. This was possible because exposure to silica was low in mine $A$, where the mean concentration of radon daughters in the underground air environment was higher than the suggested limit for non-uranium miners. ${ }^{1}$ In mine $\mathrm{B}$, by contrast, exposure to

Table 5 Comparison of surface workers in the two mines: each subcohort includes all cohort members who ever held a job in surface worksites of that mine; therefore subjects who worked in both mines appear twice

\begin{tabular}{|c|c|c|c|c|c|}
\hline \multirow[b]{2}{*}{ ICD-9 code } & \multirow[b]{2}{*}{ Cause of death } & \multicolumn{2}{|c|}{ Mine $A$} & \multicolumn{2}{|c|}{ Mine $B$} \\
\hline & & Obs & $S M R(95 \% C I)$ & Obs & $\operatorname{SMR}(95 \% C I)$ \\
\hline $001-999 \cdot 9$ & All causes & 260 & $94(83-106)$ & 124 & $88(73-105)$ \\
\hline $001-139 \cdot 8$ & Infectious and parasitic diseases & 7 & $160(64-329)$ & 2 & $89(11-321)$ \\
\hline $011-011 \cdot 9$ & Pulmonary tuberculosis & 4 & $149(40-382)$ & - & $-(-)$ \\
\hline $140-239 \cdot 9$ & All cancers & 62 & $85(66-109)$ & 39 & $101(74-139)$ \\
\hline $140-149.9$ & Oral cavity and pharynx & 2 & $67(8-240)$ & 1 & $65(2-364)$ \\
\hline $150-159 \cdot 9$ & Digestive system & 20 & $81(49-125)$ & 12 & $93(48-163)$ \\
\hline $150-150.9$ & Oesophagus & 2 & $129(16-466)$ & 1 & $121(3-673)$ \\
\hline $151-151 \cdot 9$ & Stomach & 7 & $100(40-205)$ & 3 & $83(17-242)$ \\
\hline $152-154 \cdot 8$ & Intestine and rectum & 3 & $68(14-198)$ & 4 & $174(47-444)$ \\
\hline $155-155 \cdot 2$ & Liver & 5 & $81(26-190)$ & 1 & $31(1-174)$ \\
\hline $157-157 \cdot 9$ & Pancreas & 2 & $58(7-209)$ & 1 & $55(1-307)$ \\
\hline $158-158.9$ & Peritoneum and retroperitoneum & 1 & $266(7-1483)$ & 1 & $516(13-2873)$ \\
\hline $160-165.9$ & Respiratory system & 22 & $92(57-139)$ & 14 & $107(58-179)$ \\
\hline $161-161.9$ & Larynx & 3 & $96(20-280)$ & - & $-(-)$ \\
\hline $162-162 \cdot 9$ & Trachea, bronchi, lung & 19 & $92(56-144)$ & 14 & $124(68-208)$ \\
\hline $163-163.9$ & Pleura & - & $-(-)$ & - & $-(-)$ \\
\hline $185-$ & Prostate & 1 & $28(1-157)$ & 4 & $229(62-586)$ \\
\hline $188-188.9$ & Kidney & 2 & $163(20-587)$ & - & $-(-)$ \\
\hline $189-189.9$ & Bladder & 2 & $55(7-199)$ & 2 & $105(13-378)$ \\
\hline $191-192.9$ & Central nervous system & 1 & $70(2-388)$ & 1 & $129(3-721)$ \\
\hline $200-208.9$ & Lymphohaemopoietic system & 6 & $117(43-254)$ & 4 & $149(40-381)$ \\
\hline 200,202 & Non-Hodgkin's lymphomas & 2 & $176(21-635)$ & 2 & $333(40-1203)$ \\
\hline $250-250 \cdot 9$ & Diabetes & 6 & $103(38-224)$ & - & $-(-)$ \\
\hline $390-459.9$ & Cardiovascular diseases & 67 & $65(51-83)$ & 21 & $41(26-63)$ \\
\hline $460-519 \cdot 9$ & Respiratory diseases & 28 & $113(75-164)$ & 47 & $376(276-500)$ \\
\hline $520-579 \cdot 9$ & Digestive diseases & 21 & $78(48-119)$ & 4 & $28(8-72)$ \\
\hline $571-571 \cdot 9$ & Liver cirrhosis & 9 & $50(36-110)$ & 2 & $21(2-75)$ \\
\hline $580-599.9$ & Urinary diseases & 11 & $244(122-436)$ & 1 & $45(1-253)$ \\
\hline $800-999.9$ & External causes & 30 & $129(87-185)$ & 8 & $68(29-133)$ \\
\hline
\end{tabular}


Table 6 Non-malignant respiratory diseases (NMRD), pulmonary tuberculosis, and lung cancer by years of employment in surface jobs and mine

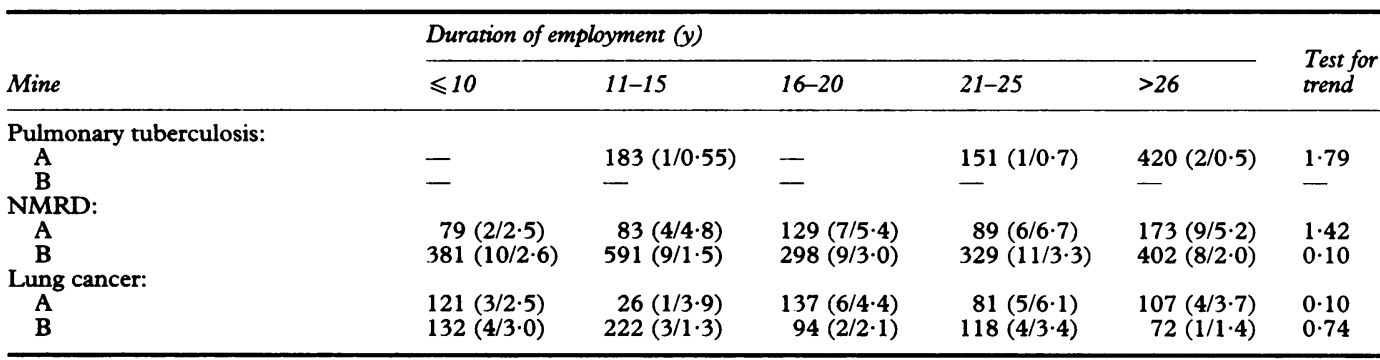

silica was high, but the concentration of radon daughters in the underground environment was estimated to be very low.

In spite of an effective selection of the workforce, as testified by very low SMRs for cardiovascular diseases and diabetes, no healthy worker effect was found among members of the present cohort. This was mainly due to a significant excess mortality from nonmalignant respiratory diseases (including silicosis) among underground workers (2.5-fold in mine A and 5/2-fold in mine B). Although no trend with duration of employment was found among underground workers from mine A, SMRs for non-malignant respiratory diseases tended to increase among underground workers in mine $B$ with $<20$ years of employment, and then to decline among subjects employed for longer periods. This figure may be due to subjects with symptoms of respiratory disorders leaving the workplace earlier than their healthy colleagues, thus only apparently contradicting duration of employment in the underground jobs in mine $\mathrm{B}$ as a reliable marker for exposure to silica. In fact, the same trend was significant after allowing for $\geqslant 26$ years from the start of employment in underground jobs (Poisson trend statistic = $4.4,1 \mathrm{df}, \mathrm{P}<0.05)$. Silicosis would plausibly have shown a stronger association with years of employment in underground jobs in mine $B$, but reliability of death certificates for diagnosis of silicosis was considered too poor to warrant a separate analysis. Deaths from pulmonary tuberculosis also contributed to the significant $20 \%$ excess mortality found among underground workers from mine B. Risks were highest after 11-15 years of employment (SMR 1059; 10 observed cases $v \quad 0.9$ expected) and 16-20 years from the start of exposure. No deaths from pulmonary tuberculosis were registered among subjects employed $\geqslant 21$ years in underground jobs in mine $B$. The same pattern was found on allowing $\geqslant 26$ or more years from the start of employment in underground jobs. No increase in risk of pulmonary tuberculosis and non-malignant respiratory disease by years of employment was found among underground miners in mine A or among surface workers of both mines.

The association of rheumatoid arthritis with silicosis is known as Caplan's syndrome, from the name of the author who first described peculiar features of the silicotic nodules among Welsh coal miners with rheumatoid arthritis. ${ }^{29}$ In subsequent years, the occurrence of rheumatoid arthritis among both patients with silicosis and workers exposed to silica has frequently been described, but only recently has epidemiological support been provided to the clinical observation of an increased occurrence of rheumatoid arthritis among workers exposed to silica. ${ }^{730}$ Three cases of rheumatoid arthritis were found among cohort members in our study, two as underlying cause of death and one as contributory disease in a subject who died from respiratory failure subsequent to silicosis. All cases occurred among underground workers in mine B employed for 5-11 years, which is consistent with the hypothesis of an association with immunological disorders related to exposure to silica. ${ }^{7}$ Occupational exposure to silica is also considered among aetiologies of scleroderma, ${ }^{31}$ but no cases of scleroderma or other diseases of the immune system were listed as either underlying or contributory causes of death in the death certificates of cohort members.

Animal $^{32}$ and human studies ${ }^{33}$ have pointed to the potential nephrotoxicity of crystalline silica, and an increased risk of deaths from renal diseases has been found repeatedly in epidemiological studies of workers exposed to silica. ${ }^{61730}$ Reference rates used in our study for calculating expected numbers did not consider renal diseases separately, so that only risks for the general group of genitourinary diseases were calculated. Renal diseases, mostly glomerulonephritis and kidney failure, accounted for $28 / 29$ deaths from genitourinary disease. Although deaths from glomerulonephritis were evenly distributed between underground and surface workers, kidney failure affected mostly underground workers of both mines, suggesting that the issue deserves detailed consideration in future studies.

In mine A, a 2.5-fold increase in the SMR for non-malignant respiratory diseases was found among underground workers. A 15\% increase in the SMR for lung cancer was also shown, with a tendency to increase by duration of employment, which in this mine is a surrogate for exposure to radon daughters. Workers in mine $A$ with $\geqslant 26$ years of employment in underground jobs, who may have experienced cumulative exposures to radon daughters up to 120 working level months (WLM) had a twofold increase in mortality from lung cancer. This figure, although not significant, is consistent with other reports. ${ }^{33}$ Underground workers in mine $B$ had a fivefold increase in mortality from 
non-malignant respiratory disease (mostly silicosis) and a sevenfold increase from pulmonary tuberculosis, although lung cancer was below the expectation.

The excess in lung cancer found among underground workers in mine $\mathrm{A}$ is certainly within the range that may be due to a confounding effect of smoking. Data from the 1973 cross sectional survey showed that smoking habits were comparable among workers at the two mines, with current smokers accounting for $64.7 \%$ in the mine $\mathrm{A}$ and $67 \cdot 1 \%$ in the mine $B$ workforce; corresponding figures for former smokers were 7.9 and $7 \cdot 2 \% .{ }^{24}$ National and regional data on smoking habits are available for the general male population aged $>11^{34}$ or $>14^{35}$ not broken down by age groups, thus not directly comparable with the mining population surveyed in 1973. A survey on smoking habits among students in northern Sardinia found that current smokers accounted for $26 \%$ of males aged $11-20$, and the same proportion was $63 \%$ at age $20 .{ }^{36}$ This figure is probably the closest to the general Sardinian male population of the same age as miners surveyed in 1973 , but it is not sufficiently precise to estimate the confounding effect of smoking on risk of lung cancer in our cohort study. Other authors used the SMR for cancer sites other than the lung that are presumably related to smoking (oral cavity, pancreas, larynx, kidney, and bladder) to evaluate the confounding effect on the risk estimate for lung cancer. ${ }^{5} \mathrm{With}$ the same approach, a total of 16 deaths from those cancers were observed among underground miners in mine A $v 16.7$ expected, and 21 were observed $v 21.5$ expected among underground miners in mine $B$. These figures indirectly suggest that smoking was unlikely to bias greatly the present results.

Some authors suggest that a large excess mortality from non-malignant causes may conceal an increased risk of lung cancer. ${ }^{37}$ In our study, a sevenfold excess mortality for pulmonary tuberculosis and a fivefold excess for non-malignant respiratory diseases occurred among underground workers with the highest exposure to silica. The very low SMRs for cardiovascular diseases and diabetes indicate that a very careful medical selection occurred before employment, particularly among underground workers from mine $B$, which partially compensated for the excesses of diseases causally related to exposure to silica-such as silicosis (included among non-malignant respiratory diseases)or strongly associated with silicosis-such as tuberculosis. It is not clear why the increased occurrence of diseases reportedly associated with lung cancer, accompanied by only a slight increase in mortality from all causes, should obscure, rather than be accompanied by, increased mortality from lung cancer. Although duration of employment was only a poor surrogate for dose in this study, it is conceivable that the difference in the cumulative dose of $\alpha$ radiation absorbed in the underground environment of the two mines may have contributed to generating the different pattern of mortality from lung cancer. Indeed, although the 1973 cross sectional survey showed that the proportion of workers with airways obstruction was similar in the two mines, ${ }^{26}$ an excess risk of lung cancer was found only among underground workers in mine A.

Obstructive impairment of lung function is known to be a strong predictor of mortality from lung cancer, ${ }^{38-40}$ and various degrees of airways obstruction are frequently associated with silicosis, which is typically a parenchymal disorder. ${ }^{41}$ Carta et $a l^{13}$ showed that patients with silicosis who had airways obstruction ran the highest risk of lung cancer. Besides being a possible early symptom of lung cancer, airways obstruction was also suggested as contributing to its development as it slows the mucociliary clearance of inhaled particles. ${ }^{38}$ Under these conditions, particles tend to pool in areas where mucociliary clearance is apparently less effective, as in the central airways. This is typically the site where most lung cancers occur among smokers, who most frequently suffer from chronic airways obstruction. ${ }^{35}$ The risk of lung cancer associated with airways obstruction among nonsmokers is higher for tumours of the central airways, such as squamous cell and small cell cancer of the lung, than for adenocarcinoma, typically located peripherally. ${ }^{4042}$ This provides further support for the hypothesis that airways obstruction contributes to an enhanced risk of lung cancer by increasing the effective dose of lung carcinogens at the level of target tissue.

In a recent review of previous experimental studies, Holland suggested that evidence for a positive association between exposure to silica and lung cancer is insufficient for setting new regulatory limits. ${ }^{3}$ Alternatively, long term inhalation experiments on Fisher 344 rats with silica at concentrations 10 times lower than previous studies have shown an increased rate of lung tumours among animals treated with silica. ${ }^{43}$ These tumours were associated with central fibrosis; concomitant findings were lipoproteinosis, inflammation, and epithelial hyperplasia. These features suggest effects from dust overloading, and may be generally attributable to the suppression of particle transport by type II alveolar macrophages. ${ }^{44}$ The extent of suppression seems to depend on the volume of dust phagocytised by the alveolar macrophage pool. ${ }^{44}$ The same physiological events have been shown to occur with all interactions between particles and alveolar macrophages including dusts previously regarded as benign. Presumably, these effects are also accentuated by surface properties of the particles, their intrinsic toxicity, and the persistence of dust carrying macrophages within the alveolar interstitium. ${ }^{44}$ Although the relevance of this condition to lung carcinogenesis is still unknown, chemical mediators of the inflammatory response have been shown to be related to hyperplasia of epithelial cells. ${ }^{45}$

Inhaled dusts, including silica, alone or with smoking and other irritant gases such as 
nitrogen and sulphur oxides, may cause airways obstruction. ${ }^{46}$ They may also transport carcinogens, such as $\alpha$ particles into the lungs. Dusts may also enhance the effective dose of transported carcinogens at the level of bronchioalveolar tissue because of delayed mucociliar clearance. The condition of dust overloading, and the consequent release of chemical mediators by type II alveolar macrophages, typical of silicosis, allows closer contact between the DNA of epithelial cells and oxygen free radicals, and may further promote the carcinogenic process. The association of a single risk factor with lung cancer may vary across different working populations according to dietary habits, levels of exposure to other lung carcinogens from workplace conditions or personal habits, and genetic characteristics, including the morphology of the bronchial tree, which in turn influences the likelihood of developing an obstructive impairment. Under the assumption of a multifactorial model of the etiology of lung cancer, inconsistencies across studies on lung cancer and silica or silicosis may be expected if every other component of the "sufficient cause" is not properly considered in each study. ${ }^{47}$

As far as other cancer sites are concerned, the large SMR for peritoneal and retroperitoneal cancer was an unexpected finding and was mainly found among underground workers in mine A. Although knowledge on occupational risk factors for retroperitoneal sarcomas is still scanty, numbers are too small to draw any inference on peritoneal cancer as related to asbestos exposure in mine $A$, and no information is presently available about such exposure in the two mines. An increased mortality from lymphohaemopoietic malignancies was reported in previous studies of patients with silicosis ${ }^{6}$ and Italian pyrite miners. ${ }^{33}$ Five out of 10 deaths from lymphohaemopoietic tumours found among Italian pyrite miners were lymphosarcomas and reticulosarcomas, with a 3.2-fold excess of borderline statistical significance. ${ }^{33}$ In our study, where lymphosarcoma and reticulosarcoma were included among non-Hodgkin's lymphomas with other malignancies of the lymphoid and hystiocytic tissue (ICD-9 codes 200 and 202), four deaths from nonHodgkin's lymphoma occurred among surface workers, two of which were in mine B with an SMR of 333. This figure does not support an association with exposure to silica, but numbers are too small to allow a detailed investigation of associations with other workplace exposures.

Incomplete knowledge on all workplace exposures and use of duration of employment as a surrogate for dose suggests cautious conclusions. Nevertheless, these findings are consistent with low level exposure to radon daughters as a risk factor for lung cancer among metal miners. They also show that differences in exposure to silica, as in the two mines in the present study, were not accompanied by consistent increases in lung cancer risk.
We acknowledge the contribution of Miss M Elisabetta Loy, Mr Eugenio Maccioni, Mr Franco Maxia, and Mr Ignazio Meloni in collecting data. We also thank Miss Celestina Sanna, director of the Historical Archives of the Municipality of Iglesias (Cagliari-Sardinia), for her collaboration.

1 International Agency for Research on Cancer. Monographs on the evaluation of carcinogenic risks to humans. Vol 42. Silica and some silicates. Lyon: IARC, 1987.

2 Simonato L, Saracci R. Epidemiological aspects of the relationship between exposure to silica dust and lung cancer. In: Simonato L, Fletcher AC, Saracci R, Thomas TL, eds. Occupational exposure to silica and cancer risk. Lyon: International Agency for Research on Cancer, 1990:1-5. (IARC Sci Publ No 97).

3 Holland LM. Crystalline silica and lung cancer: a review of recent experimental evidence. Regul Toxicol Pharmacol 1990;12:224-37.

4 Mastrangelo G, Zambon P, Simonato L, Rizzi P. A casereferent study investigating the relationship between exposure to silica dust and lung cancer. Int Arch Occup Environ Health 1988;60:299-302.

5 Merlo F, Fontana L, Reggiardo G, Ceppi M, Barisione G, Doria $M$. Mortality from lung cancer among 515 silicotic subjects: results for the follow-up period 19611987. In: Rabovky J, Coolins J, Dement J, Goldsmith 1987. In: Rabovky J, Coolins J, Dement J, Goldsmith Symposium on Silica, Silicosis and Cancer. Vol II. San Symposium on Silica, Silicosis and Cancer. Vol II. San
Francisco, CA: Western Consortium for Public Health Francisco, CA:

6 Amandus HE, Shy C, Wing S, Blair A, Heinemann EF. Silicosis and lung cancer in North Carolina dusty trades workers. Am ₹ Ind Med 1991;20:57-70.

7 Steenland K, Beaumont J. A proportionate mortality study of granite cutters. Am f Ind Med 1986;9:189-201.

8 Amandus HE, Costello J. Silicosis and lung cancer in US metal miners. Arch Environ Health 1991;46:82-9.

$9 \mathrm{Ng} \mathrm{TP}$, Chan SL, Lee J. Mortality of a cohort of men in a silicosis register: further evidence of an association with silicosis register: further evidence of an associa

10 Chia SE, Chia KS, Phoon WH, Lee HP. Silicosis and lung cancer among Chinese granite workers. Scand $\mathcal{f}$ Work Environ Health 1991;17:170-4.

11 Hessel PA, Sluis-Cremer GK, Hnizdo E. Silica exposure, silicosis and lung cancer: a necropsy study. $\mathrm{Br} F$ Ind $\mathrm{Med}$ 1990;47:4-9.

12 Hnizdo E, Sluis-Cremer GK. Silica exposure, silicosis and lung cancer: a mortality study of South African gold miners. Br F Ind Med 1991;48:53-60.

13 Carta P, Cocco PL, Casula D. Mortality from lung cancer among Sardinian patients with silicosis. $\mathrm{Br} \mathcal{F}$ Ind $\mathrm{Med}$ 1991;48:122-9.

14 Merlo F, Costantini M, Reggiardo G, Ceppi M, Puntoni R. Lung cancer risk among refractory brick workers exposed to crystalline silica: a retrospective cohort study. Exposed to crystalline silica: a r

15 Koskela RS, Klockars M, Jarvinien E, Kolari PJ, Rossi A. Cancer mortality of granite workers. Scand $\mathcal{f}$ Work Environ Health 1987;13:26-31.

16 Thomas TL, Stewart P. Mortality from lung cancer and respiratory disease among pottery workers exposed to silica and talc. Am $\mathcal{F}$ Epidemiol 1987;125:35-43.

17 Checkoway H, Heyer NJ, Demers PA, Breslow NE. Mortality among workers in the diatomaceous earth industry. Br F Ind Med 1993;50:586-97.

18 McLaughlin JK, Chen J-Q, Dosemeci M, et al. A nested case-control study of lung cancer among silica exposed case-control study of lung cancer among silica expo
workers in China. Br $\mathcal{7}$ Ind Med 1992;49:167-71.

19 Costello J, Graham WGB. Vermont granite workers' mortality study. Am f Ind Med 1988;13:483-97.

20 Chen SY, Hayes RB, Liang SR, Li QC, Stewart PA, Blair A. Mortality experience of haematite mine workers in China. Brf Ind Med 1990;47:175-81.

21 National Institute for Occupational Safety and Health (NIOSH). A recommended standard for occupational exposure to radon progeny in underground miners. Washington DC: Department of Health and Human Services, US Government Printing Office, 1987. (DHHS (NIOSH) publ No 88-101.)

22 Ahlman K, Koskela RS, Kuiskka P, Koponene M Annanmaki $M$. Mortality among sulphide ore miners. Annanmaki M. Mortality amo

23 Kuisak RA, Springer J, Ritchie AC, Muller J. Carcinoma of the lung in Ontario gold miners: possible aetiological factors. Br F Ind Med 1991;48:808-17.

24 Carta P, Cocco PL, Picchiri GF. Lung cancer mortality and airways obstruction among metal miners exposed to silica and low levels of radon-daughters. Am $\mathcal{F}$ Ind Med 1994;25:489-506.

25 Casula D. Aspetti diagnostici della silicosi. In: Valdes $P$, ed. Proceedings of the second national conference on silicosis, vol 1. Cagliari: Valdes, $1965,25-60$.

26 Casula D, Cherchi P, Sanna Randaccio F, et al. Piano di lotta contro la silicosi e le altre pneumoconiosi di particolare importanza per la Sardegna. Cagliari: Valdes, 1982.

27 Casula D, Carta P, Sanna Randaccio F. Environmental conditions in Sardinian metalliferous mines. In: Proceedings of the sixth International Pneumoconiosis Conference, Bochum, 1983. Vol 3. Geneva: International Conference, Bochum, 1983. Vol 
28 Marsh GM, Preininger M, Ehland JJ. OCMAP PC: occupational cohort mortality analysis program. Pittsburgh PA tional cohort mortality analysis
University of Pittsburgh, 1989 .

29 Caplan A. Certain unusual radiological appearances in the chest of coalminers suffering from rheumatoid arthritis. Thorax 1953;8:29-37.

30 Koskela RS, Klockars M, Jarvinien E, Kolari PJ, Rossi A Mortality and disability among granite workers. Scand $\mathcal{f}$ Work Environ Health 1987;13:18-25.

31 Crepy MN, Conso F. Sclerodermie et facteurs professionnels (ou environmentaux). Archives des Maladies Professionelles 1994;55:111-8.

$32 \mathrm{Ng}$ TP, Ng YL, Lee HS, Chia KS, Ong HY. A study of silica nephrotoxicity in exposed silicotic and non-silicotic workers. Br f Ind Med 1992;49:35-7.

33 Battista G, Belli S, Carboncini F, et al. Mortality among pyrite miners with low-level exposure to radon daughpyrite miners with low-level exposure to radon

34 Istituto Nazionale di Statistica. Indagine Statistica sulle condizioni di salute della popolazione e sul ricorso ai servizi sanitari. Novembre 1983: note e relazioni $n$ 1. Rome: ISTAT, 1986

35 Istituto Nazionale di Statistica. Indagine Statistica sulle condizioni di salute della popolazione e sul ricorso ai servizi sanitari. Novembre 1986-Aprile 1987: note e relazioni $n 2$. Rome: ISTAT, 1991

36 Maida A, Mura I, Muresu E, Romano G, Ruggiu M, Sech A. Indagine sull'abitudine al fumo tra gli studenti d Alghero (Sassari). Studi Sassaresi 1980;58:469-95.

37 Amandus HE, Castellan RM, Shy C, Heinemann EF, Blair A. Reevaluation of silicosis and lung cancer in Blair A. Reevaluation of silicosis and lung cancer in 1992;22:147-53.

38 Skillrud DM, Offord KP, Miller RD. Higher risk of lung cancer in chronic obstructive pulmonary disease. Ann Intern Med 1986;1105:503-7.

39 Beaty TH, Cohen BH, Newill CA, Menkes HA, Diamond $\mathrm{EL}$, Chen CJ. Impaired pulmonary function as a risk facEL, Chen CJ. Impaired pulmonary function as a risk

40 Alavanja MCR, Brownson RC, Boice JD, Hock E Preexisting lung disease and lung cancer among nonsmoking women. Am f Epidemiol 1992;136:623-32.

41 Sanna Randaccio F. Broncopneumopatie professionali. In Casula D, ed. Medicina del Lavoro. Bologna: Monduzzi, 1993, 450-82.

42 Nomura A, Stemmermann GN, Chyou PH, Marcus EB Buist $S$. Prospective study of pulmonary function and lung cancer. Am Rev Respir Dis 1991;144:307-11.

43 Muhle H, Kittel B, Ernst H, Mohr U, Mermelstein R. Neoplastic lung lesions in the rat after chronic exposure to crystalline silica. In: Rabovky J, Coolins J, Dement J Goldsmith DF, et al., eds. Syllabus of the second International Symposium on Silica, Silicosis and International Symposium on Silica, Silicosis and for Public Health 1993, 154-8.

44 Morrow PE. Dust overloading of the lungs: update and appraisal. Toxicol Appl Pharmacol 1992;113:1-12.

45 Williams AO, Flanders KC, Saffiotti U. Immunohistochemical localization of transforming growth factor$\beta 1$ in rats with experimental silicosis, alveolar type Il hyperplasia, and lung cancer. Toxicol Appl Pharmacol 1993;142:1831-40.

46 Carta P, Cocco PL, Aru G, Barbieri MT, Cocco E, Meloni M. Smoking and dust effect upon lung function of healthy workers. Eur $\mathcal{J}$ Respir Dis 1981;62 (suppl 113): healthy.

47 Rothman KJ. Modern epidemiology. Boston, MA: Little, Brown, 1986. 